\title{
Urban Expansion Analysis and Land Use Changes in Rangpur City Corporation Area, Bangladesh, using Remote Sensing (RS) and Geographic Information System (GIS) Techniques
}

\author{
Md Naimur Rahman \\ Department of Geography and Environmental Science, Begum Rokeya University \\ Rangpur City Bypass, Rangpur 5400, Bangladesh \\ Email: 01naimur@gmail.com
}

Received 24 September 2019/ Revised 27 October 2019/ Accepted 6 November 2019/ Published 1 December 2019/

Available Online 25 November 2019

\begin{abstract}
This study aim to attempt mapping out the Land Use ar Land Cover (LULC) status of Regional Project Coordination Committee (RPCC) between 2009-2019 with a view of detecting the land consumption rate and the changes that has taken place using RS and GIS techniques; serving as a precursor to the further study on urban induced variations or change in weather pattern of the cityn Rangpur City Corporation(RCC) is the naim administrative functional area for both of Rangpur City and Rangpur division and experiencing a rapid changes in the field of urban sprawl, cultural and physical landscape,city growth. These agents of Land use or Land cover (LULC) varieties are responsible for multi-dimensional problems such as traffic congestion, waterlogging, and solid waste disposal, loss of agricultural land. In this regard, this study fulfills LULC changes by using Geographical Information Systems (GIS) and Remote Sensing (RS) as well as field survey was conducted for the measurement of change detection. The sources of data were Landsat 7 ETM and landsat 8 OLI/TIRS of both C1 level 1. Then after correcting the data, geometrically and radiometrically change detection and combined classification (supervised \& unsupervised) were used. The study finds LULC changes built-up area, water source, agricultural land, bare soil in a change of percentage is $17.23,2.58,-9.94,-10.19$ respectively between 2009 and 2019. Among these changes, bare soil is changed to a great extent, which indicates the expansion of urban areas is utilizing the land to a proper extent.
\end{abstract}

Keywords: Urban expansion; land use; land cover; remote sensing; geographic information system (GIS); Rangpur City Corporation(RCC).

\section{Introduction}

Bangladesh is a developing country with the rapid growth of the population. Rangpur is also a fast-growing city in the field of urbanization, with having a population of 2.96 million. Because of the fastest population growth LULC also changing the emphasizes function of 
urbanization. A satellite image is carrying many more essentialities for the proper and quick planning of LULC. For this reason, the field surveying method is considering time-consuming and costly, which is replacing by RS techniques.

Fasal (2000) asserted the nature of land use changes, location of agricultural land losses and for the reason of urbanization the supply of higher quality of agricultural activities is reducing. Remote sensing satellites are playing a vital role in mapping land use and land cover changes and infrastructural development for several past recent years (Arimoro et al., 2003). But in RCC no such application is implemented for the detection and assessment of these types of operational work (Dewan and Yamaguchi, 2009). Land use changes arising from agriculture, pasturing, urbanization, bare soil and deforestation are some of the responsible factors to land cover changes in RCC. These changes in LULC reflect on the growth of population, consumption of land and the local climate. Expansion of RCC has resulted not only in the depletion of natural resources, but a deterioration of the environment. Agriculturally productive land, forestland, bare land have been transformed into different commercial, residential and other uses. The LULC is the result of social, economic, fenvironmental phenomenon and their perspective of utilization. The collection of remotely sensed data contributes to the synoptic assessments of the function of earth-system, patterning, and change at local, regional , and global scales over time (Rajeshwari, 2006).

However, the objective of this study is to attempt mapping out the LULC status of RPCC between 2009-2019 with a view ofdetecting the land consumption rate and the changes that has taken place using RS and GIS techniques; serving as a precursor to the further study on urban induced variations or change in weather pattern of the city. The changes of rapid land use are the cause of a growing population, which is reducing another area of interest like natural vegetation (Nicolson, 1987). The urban centers are increasing in population, but a two-fold conversion is undergoing for the pre-urban areas; arable and non-arable land both are providing increasingly numbered of establishments such as commercial, industrial and residential (Heimlich and Anderson, 2001). Kalnay and Cai (2003) assessed that the urban area and surroundings could be altered by the local climate, which is the cause of urban expansion. Instead of using traditional approaches, satellite remote sensing is essentially monitoring the change of land use with the facilities of high resolution which is associated with lower cost (Belal and Moghanm, 2011). 
The LULC maps also revealed an increase in land reclamation and have an environmental impact (Fellati et al, 2017; Risma et al, 2019; Djimadoumngar, K.-N., \& Adegoke, J, 2018 ).

Al rifat and Liu (2019) found that new urban lands were generated away from the coast. Edwards et al (2019) found that a restrictive zoning regime has controlled urban sprawl. The informal settlements continue to develop rapidly in each city (Park et al, 2019). Urban area planning must consider the development of the city vertically (He et al, 2019). Land use mapping will be very helpful for proper urban area planning (Navale and Mhaske, 2019).

Previous research has not analyzed urban expansion and its relationship with coporation area, so this research has a novelty that emphasizes the interrelationship between urban expansion, land use change, corporation area , and the use of remote sensing and geographical information systems. This study aims to attempt mapping out the LULC status of RPCC between 2009-2019 with a view of detecting the land consumption rate and the changes that have taken place using RS and GIS techniques

\section{Methods}

This study utilizes data for the measurement of LULC changes. Remotely sensed data Landsat 8 and Landsat 7 of both 1 Level were used for the LULC change detection in between the year of 2019 and 2009 (aten year time span). Spatial Characteristics of these data having the below approaches (See Table 1). In addition, these data were collected from earthexplorer.usgs.gov whist pathand row were 138 and 042.

Table 1: Spatial Characteristics of Data ( Used)

\begin{tabular}{ccccc}
\hline Instrument & $\begin{array}{c}\text { Month/ year of } \\
\text { Image }\end{array}$ & Sensors & $\begin{array}{c}\text { Spatial } \\
\text { Resolution }\end{array}$ & $\begin{array}{c}\text { Radiometric } \\
\text { resolution (bit) }\end{array}$ \\
\hline Landsat 7 & February 2009 & ETM+ & 30 & 16 \\
Landsat 8 & May 2019 & OLI/TIRS & 30 & 12 \\
\hline
\end{tabular}

Universal Transverse Mercator (UTM) was used for the collected satellite images for the map projection within Zone 46 N-Datum and of the co-ordinate system World Geodetic System (WGS) 1984 and the pixel size is 30 meters. For the extraction of study area of RCC shape file of GIS was used with having the same projection of UTM and WGS 1984 , which was georeferenced. Then images were taken by Raster Processing tool under Data Management tool 
of ArcToolbox in ArcGIS 10.5. And finally, the image classification was conducted by the combination of supervised and unsupervised classification. An extensive field survey was performed of the RCC by using GPS (Global Positioning System), earlier the preprocessing and classification of satellite imagery. GPS was used for scaling the satellite image data by comparing the field data. And this fieldwork was done in the mid of February 2019.

RPCC established in 2012, which was previously known as Rangpur Pourasova ( established 1986), with having 442 village and 112 mouza. RPCC geographically located in between $25^{\circ} 38^{\prime}$ and $25^{\circ} 52^{\prime}$ North latitudes and $89^{\circ} 05^{\prime}$ and $89^{\circ} 20^{\prime}$ East longitudes. It is bounded by Nilphamari and Lalmonirhat district on the north, on the south Gaibandha, on the east Kurigram and Dinajpur on the east with having the total area of 205.70 square kilometers ( Figure 2). And Population growth change of Rangpur is +1.98 per year from 2001 to 2011 ; which was increased 865,927 in the year of 2014 (BBS 2015).
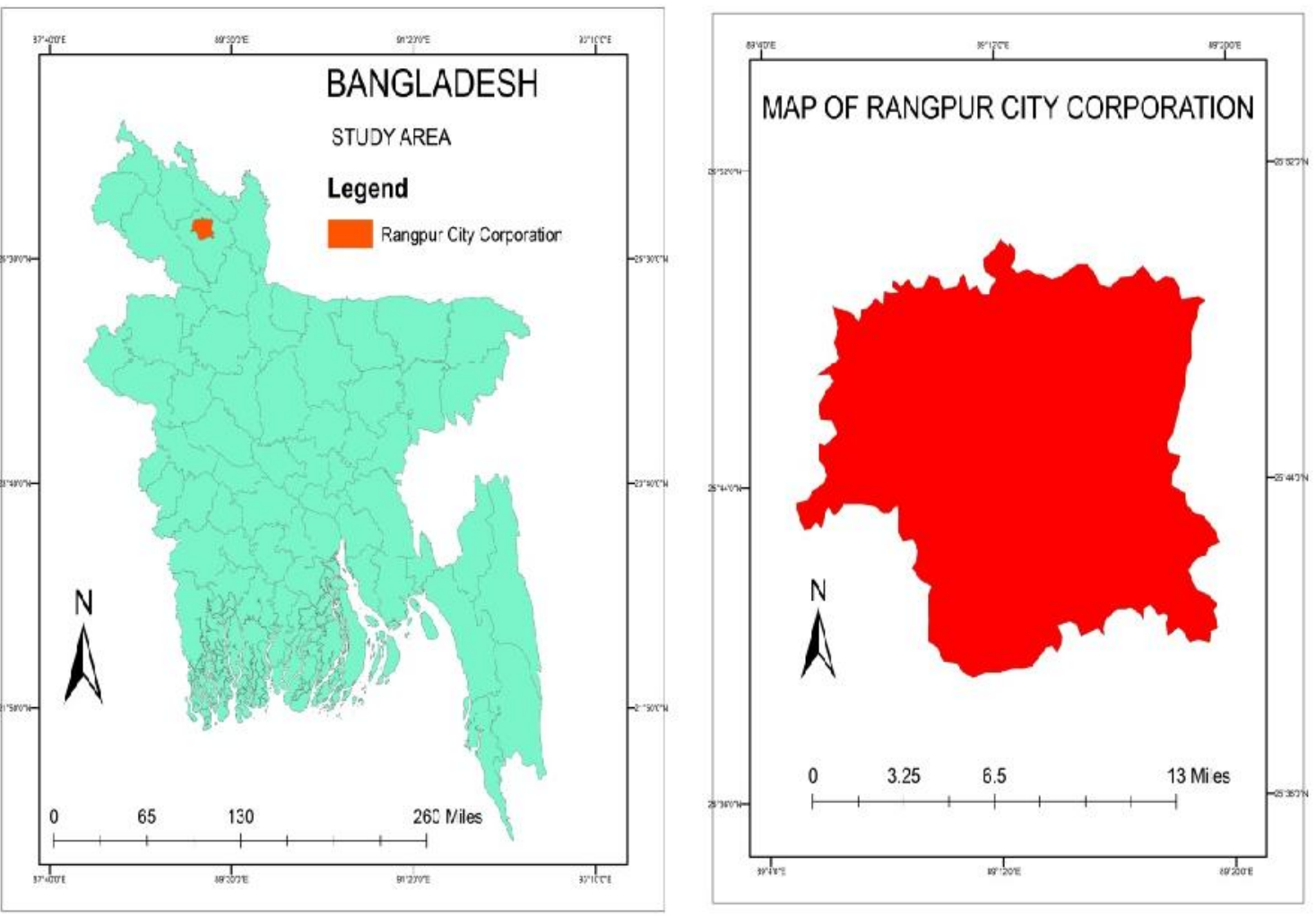

Figure 1. Study Area 


\section{Results and Discussion}

In this section, results are shown on the basis of LULC distribution, area measurement, percentage of covered area, change detection and changing pattern. The city of Rangpur gets a haphazard expansion of urban area, which is the result of conversion of agricultural and bare land. During the period of 2009 and 2019 due to the urbanization and the cause of Rangpur Pourosovaturning into RCC in 2012 has made the city expanded largely into an urban area which is 5670 hectares of 17.53 percent of total area (Table 3).

The distribution of LULC changes rapidly in the sector of a built up area which is nearly two times higher than in 2019 also, the noticeable decreases land is agricultural which is a significant indication of $10 \%$ loss. But it decreased to a great extent of bare soil from 3439 to 145 hectares(Table 2). These changes define the urban expansion where agricultural and bare soil is used to urbanized the areas. As the city population is increasing, the city has been expanded extensively to accommodate the increasing population compared to its early stage the cities spatial expansion is the modification of several constrained physical factors. However, the loss of natural resources is the cause of the development.

The LULC pattern changes spatially from 2009 to 2019 (figure 3 \& 4). Earlier in 2009 built up area was congested at the center where other parts also carried it haphazardly in the north west, north south direction. In 2019 the urban area expanded largely northward, westward and southward where the direction of eastward expansion was very low compared with them respectively. The LULC map interpretation in between 2009 and 2019 shows that RCC is expanding in all of the following directions north- west, south-west and southern parts by filling up low lying areas. The major perspective of expanding these areas is the increasing of residential, public and privet structural development.

The maximum loss of agricultural land and bare soil provides the information of the pressure of urban expansion of it. The study area urbanization is rapidly growing and if it continues it will decrease land cover areas 35.06 percent within the next 20 years which will lead to diversified and uneven expansion like present times in 2019. The contributing factors of urban sprawl are increased amount of population, poor land use policy, low land, unplanned housing 
and expansion of industrial areas, poverty, absence of multiuse of urban areas which is creating the slums and squatters with decreasing food safety due to the loss of agricultural land. These diversification is negatively affecting of both natural environment and human health as well as for the development of near future perspectives.

Table 2. Land Use Land Cover Distribution (areas in hectares)

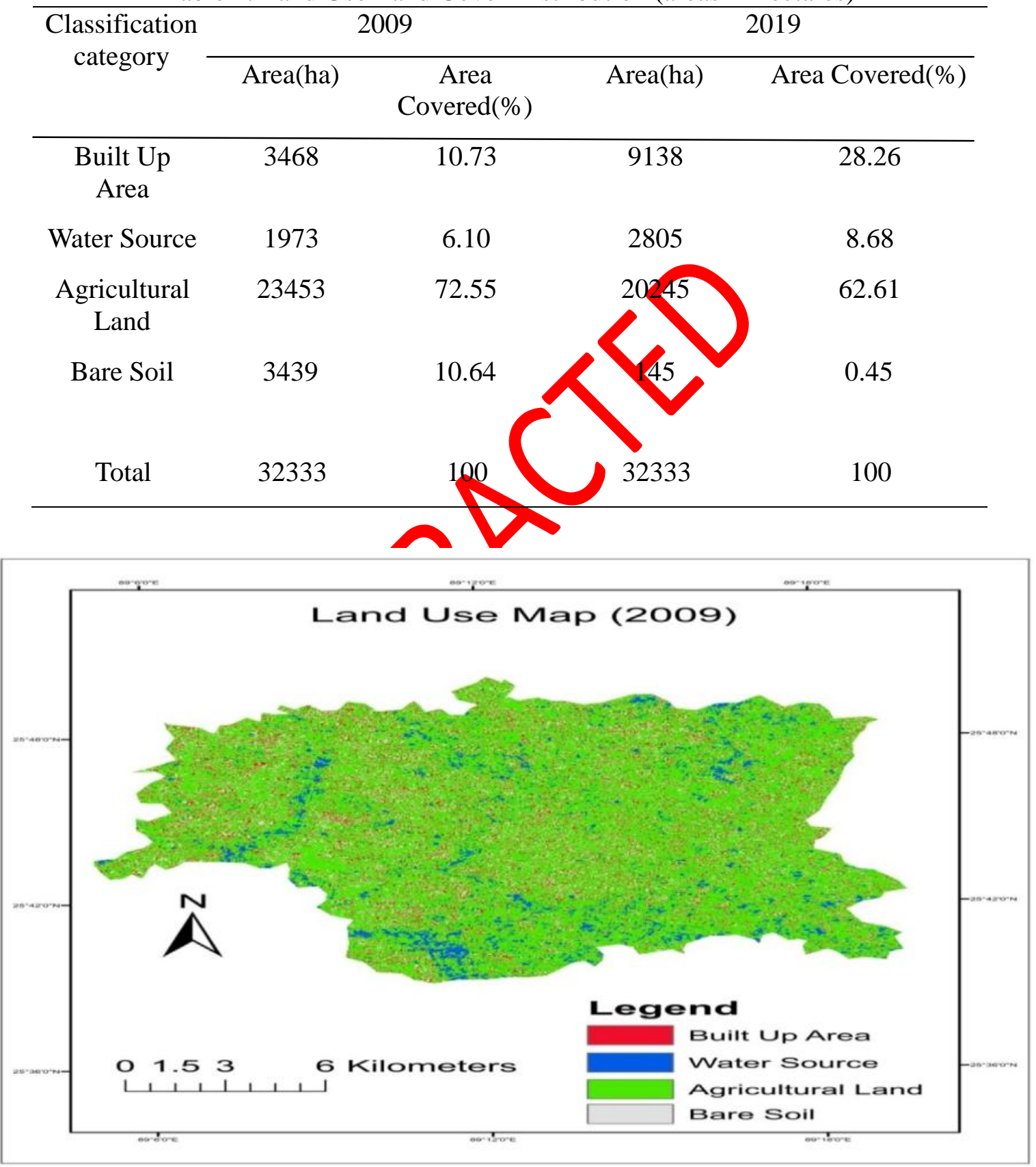

Figure 2. Land Use Map 2009 
Md Naimur Rahman / GEOSI Vol 4 No 3 (2019) 217-229

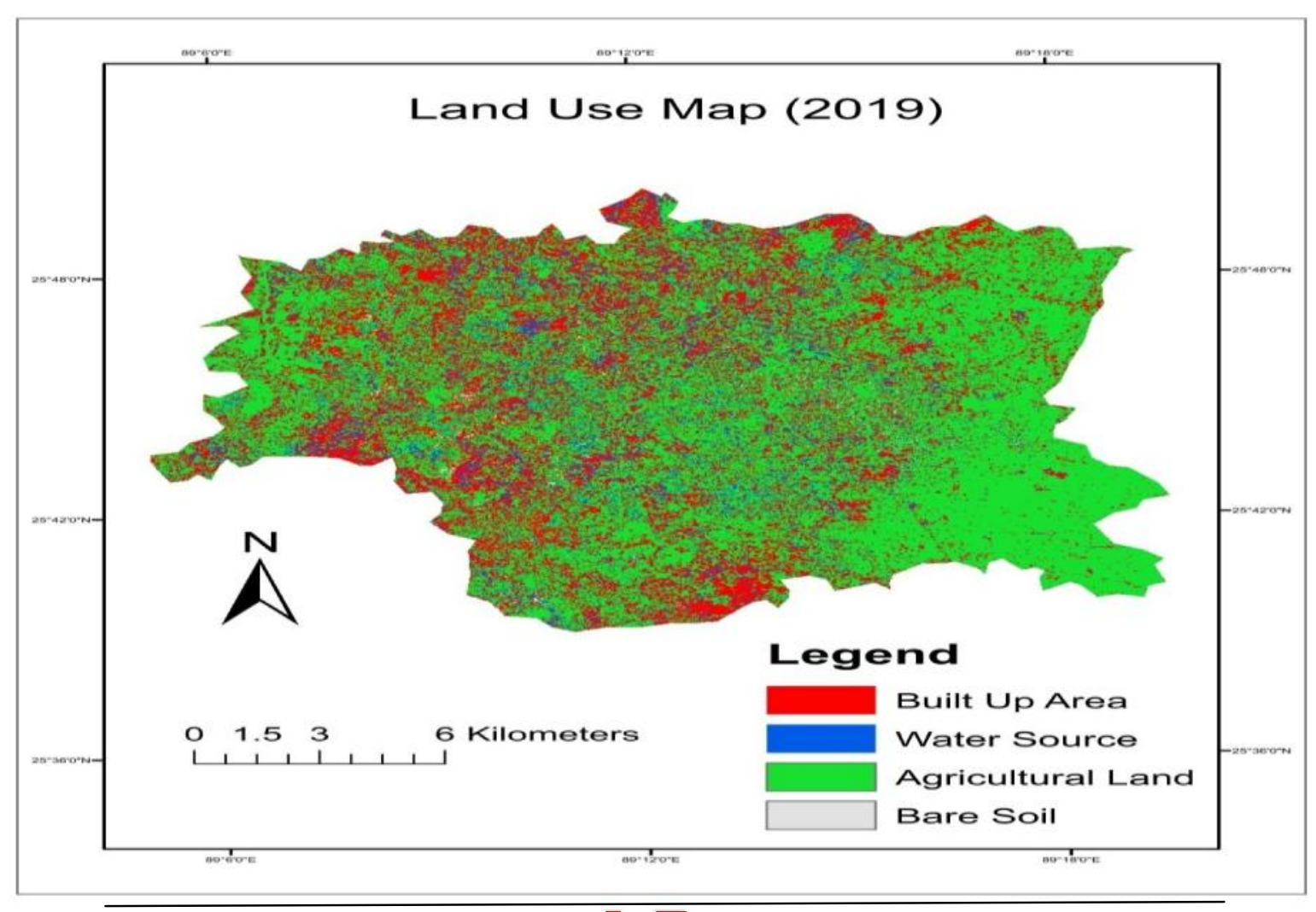

\begin{tabular}{|c|c|c|c|c|}
\hline \multicolumn{5}{|c|}{ Figure 3: Land Use Map 2019} \\
\hline $\begin{array}{c}\text { Classification } \\
\text { category }\end{array}$ & & $\begin{array}{c}2019 \\
\text { Area (ha) }\end{array}$ & $\begin{array}{c}\text { Difference in } \\
\text { Area(ha) }\end{array}$ & $\begin{array}{c}\text { Difference in } \\
\text { Area }(\%)\end{array}$ \\
\hline$\overline{\text { Built Up Area }}$ & 3468 & 9138 & 5670 & 17.53 \\
\hline Water Source & 1973 & 2805 & 832 & 2.58 \\
\hline $\begin{array}{l}\text { Agricultural } \\
\text { Land }\end{array}$ & 23453 & 20245 & -3208 & -9.94 \\
\hline Bare Soil & 3439 & 145 & -3294 & -10.19 \\
\hline
\end{tabular}


Md Naimur Rahman / GEOSI Vol 4 No 3 (2019) 217-229

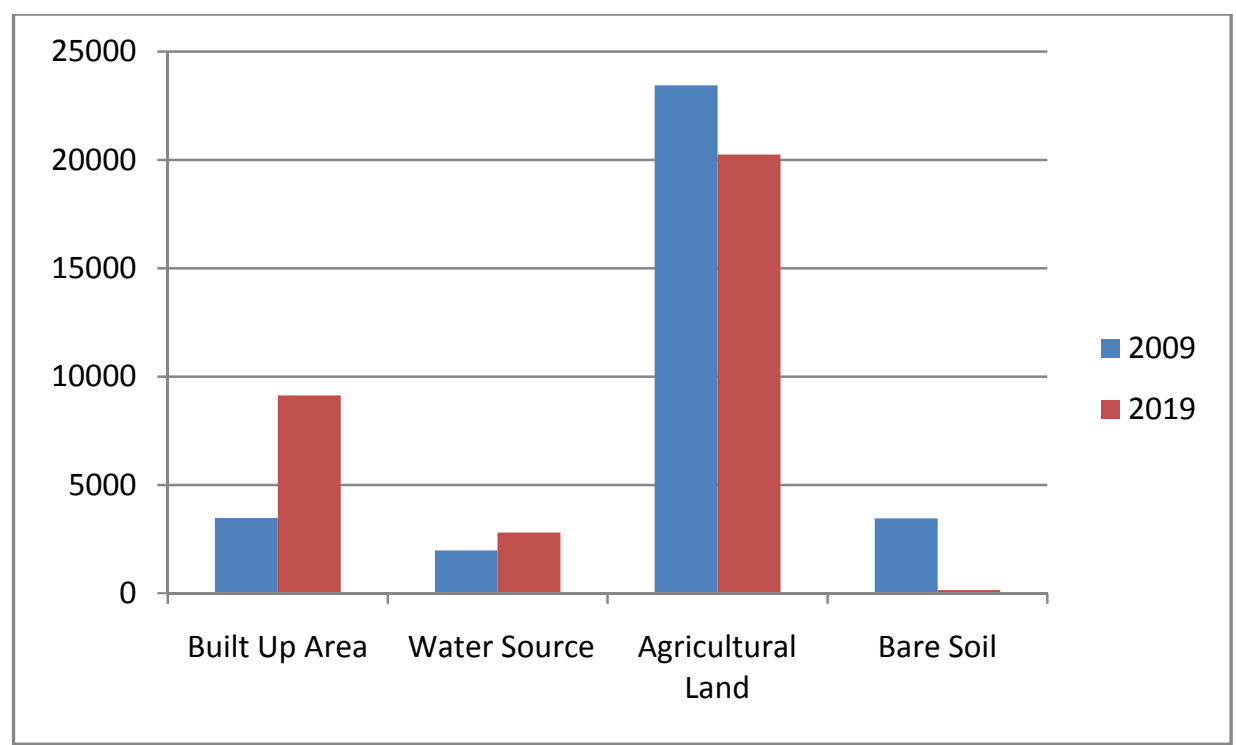

Figure 4. LULC Change Detection between 2009 \& 2019

Results of Table 2 and Figure 3, 4 makes an evidence of congestion of the city and haphazardly increasing number of built up area which includes residential, commercial and services, industrial, transportation, roads, mixed urban, and other urban areas within the percentage of 17.53(5670 ha) where with the same increasing trend water source also got improvement. The responsible factors for these urban expansions are mainly population growth and haphazard development of residential,industrial as well as public infrastructure. And the improvement and increased amount of water bodies proves that permanent water sources like river, permanent open water, lakes, ponds and reservoirs are extended whereas temporal or seasonal water sources like permanent and seasonal wetlands, marshy land, swamps have been decreased. 3208 hectares of agricultural land are negatively increased due to the positively extent of built up area of 5670 hectares where agricultural land indicates the agents of both cultivated and planted trees like crop fields, fallow lands, vegetable lands, roadside planted trees, mixed forest lands, homestead forest. The bare soil is providing space both for the built up area and permanent water source and for this reason, it is increased negatively of 10.19 percent of 145 hectares of the 10 years span of time. In a very recent period, bare soil indicates exposed soils, sand fill, landfill sites, and areas of active excavation. This reduction of agricultural land and bare soil is leading the fact of urbanization rapidly.

LULC change detection represents the result of Table 3 and figure 5 where rapid change is noticed in the factors of built up area and bare soil which is about 27.72. Their individual 
approximate change indicates the built up area is most commonly responsible for this rapid change. Beyond the changing pattern of built up area rapid growth of the population of the city( see figure 2) is playing an essential role. Bare land is negatively changed of 10.19 , which is the indication of land use efficiency.

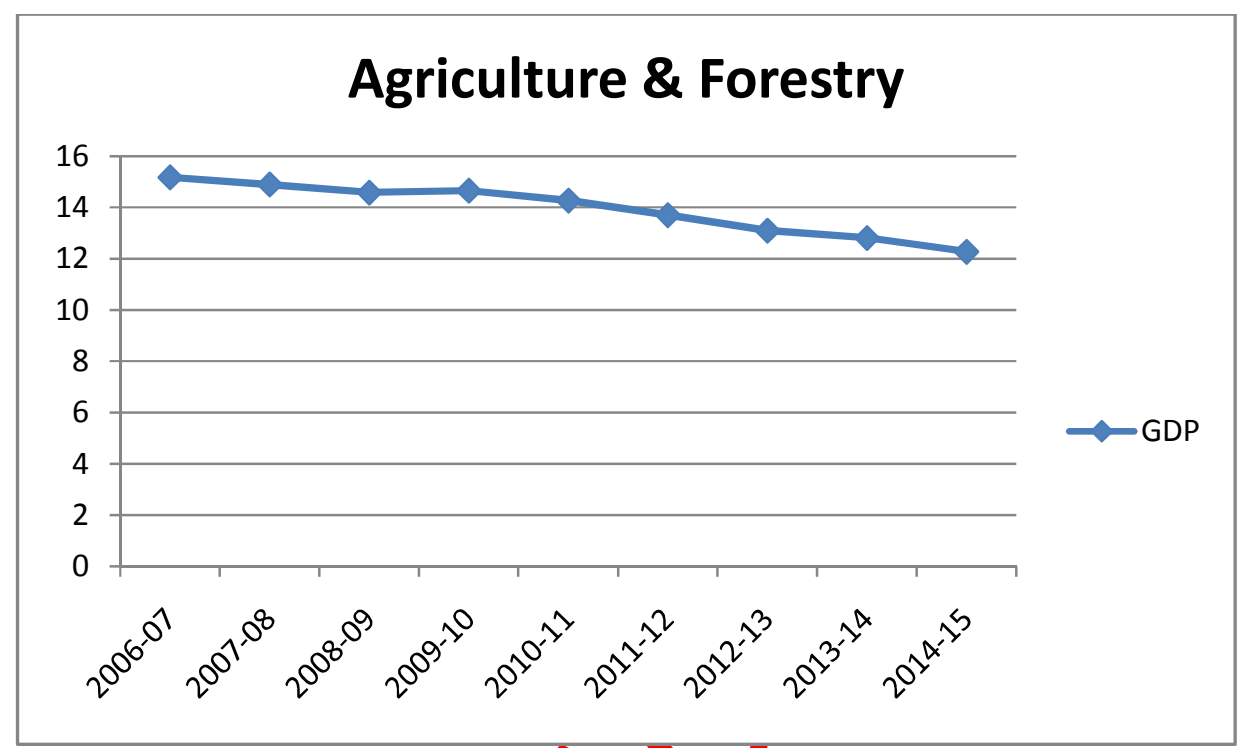

Figure 5. GDP from the sector of Agriculture and Forestry

Loss of agricultural land is the reason of gradual loss of GDP as it is the field of second largest source of GDP after manufacturing ( $20.17 \%$ GDP). As water source is increased of 2.58 percent so that agricultural activity could be benefited from it and also fisheries sector is improving for the reason of available water source (field survey). For the food safety and economic growth (see figure 6) agricultural land carries several responsibilities in Bangladesh agricultural production and $84 \%$ of rural people directly or indirectly engaged with agriculture ( Uddin, 2015). But it is decreased in RPCC of about 10 percent which is an alarming rate for the food safety.

The results of previous study indicate the suitability of the proposed indices to discriminate between urban areas, bare soil in arid, water balance, population data and semi-arid climates (Rasul et al, 2018; Schilling et al, 2008; Nong et al; 2015). Matlhodi et al (2019) found that the need for monitoring in the catchment area to avoid land degradation. Remote sensing can analyze precisely the relationship between urbanization and groundwater quality (Elbeih and 
Md Naimur Rahman / GEOSI Vol 4 No 3 (2019) 217-229

El-Zeiny, 2018). There is a negative impact on land changes to water quality of lake (Im et al, 2014). Quality water needs greatly affect patterns of land change (Mondal et al, 2014). The increase in livestock has a negative impact on water quality (Fucik et al, 2014). The results of the above studies are different from the results of this study. These differences are found in studies related to urban expansion. The impact of these findings is the need for policies related to urban expansion related to deforested land use. The advantage of this research compared to previous research is the existence of findings related to urban area planning related to LULC changes built up area, water source, agricultural land, bare soil

\section{Conclusion}

This study showed that the indication of the potential use of GIS and RS technique for obtaining the objective specific measurement of RCC. The uneven and haphazard increasing of settlement, industrial, and commercial infrastructure are rapid, hich is the indication of loss of agricultural land and bare soil. But this study also finds that the source of water is increased so this could be an indication of future development of agricultural land. And proper management of urban expansion must be implemented for the quality of cultivation; the separate zonation for the expansion of urban infrastructure could atso be conducted. Loss of agricultural land could be covered through multi structural use of existing agricultural and bare land with using the available water source. The extended recommendation proposes a future course of action for the field study to identify the category of several spheres of LULC changes.

\section{Conflict of Interest}

The author declares that there is no conflict of interest with any financial organization regarding the material discussed in the article.

\section{References}

Al Rifat, S. A., \& Liu, W. (2019). Quantifying spatiotemporal patterns and major explanatory factors of urban expansion in miami metropolitan area during 1992-2016. Remote Sensing, 11(21) doi:10.3390/rs11212493 
Md Naimur Rahman / GEOSI Vol 4 No 3 (2019) 217-229

Arimoro AO, Fagbeja MA, Eedy W. (2002). The Need and Use of Geographic Information Systems for Environmental Impact Assessment in Africa: With Example from Ten Years Experience in Nigeria. AJEAM/RAGEE, 4(2), 16-27.

Belal, A.A. and Moghanm, F.S. (2011).Detecting Urban Growth Using Remote Sensing and GIS Techniques in Al Gharbiya Governorate, Egypt.The Egyptian Journal of Remote Sensing and Space Science, 14, 73-79. http://dx.doi.org/10.1016/j.ejrs.2011.09.001

Dewan, A.M. and Yamaguchi, Y. (2009). Using Remote Sensing and GIS to Detect and Monitor and Use and Land Cover Change in Dhaka Metropolitan of Bangladesh during 1960-2005. Environmental Monitor Assessment, 150, 237- 249. Retrieved from http://dx.doi.org/10.1007/s10661-008-0226-5

Djimadoumngar, K.-N., \& Adegoke, J. (2018). Satellite-Based Assessment of Land Use and Land Cover (LULC) Changes around Lake Fitri, Republic of Chad. Journal of Sustainable Development, 11(5), 71. doi:10.5539/jsd.111n5p71

Edwards, B., Frasch, T., \& Jeyacheya, J. (2019). Evaluating the effectiveness of land-use zoning for the protection of built heritage in the bagan archaeological zone, Myanmar-A satellite remote-sensing

Policy, 88 doi:10.1016/j.landusepol.2019.104174

approach. Land

use

Fallati, L., Savini, A., Sterlacchini, S., \& Galli, P. (2017). Land use and land cover (LULC) of the Republic of the Maldives: first national map and LULC change analysis using remotesensing data. Environmental Monitoring and Assessment, 189(8). doi:10.1007/s10661017-6120-2

Fučík, P., Novák, P., \& Žížala, D. (2014). A combined statistical approach for evaluation of the effects of land use, agricultural and urban activities on stream water chemistry in small tile-drained catchments of south bohemia, czech republic. Environmental Earth Sciences, 72(6), 2195-2216. doi:10.1007/s12665-014-3131-y

Elbeih, S. F., \& El-Zeiny, A. M. (2018). Qualitative assessment of groundwater quality based on land use spectral retrieved indices: Case study sohag governorate, egypt. Remote Sensing Applications: Society and Environment, 10, 82-92. doi:10.1016/j.rsase.2018.03.001

Fasal, S. (2000). Urban expansion and loss of agricultural land - A GIS based study of Saharanpur City, India. Environment and Urbanization, 12(2), 133 - 149

He, S., Wang, X., Dong, J., Wei, B., Duan, H., Jiao, J., \& Xie, Y. (2019). Three-dimensional urban expansion analysis of valley-type cities: A case study of chengguan district, lanzhou, china. Sustainability (Switzerland), 11(20) doi:10.3390/su11205663 
Heimlich, R.E and W.D. Anderson. (2001). Development at the Urban Fringe and Beyond: Impacts on Agriculture and Rural Land. 803, Economic Research Service, U.S. Department of Agriculture, Washington D.C., pg 80

Im, N., Kawamura, K., Suwandana, E., \& Sakuno, Y. (2014). Monitoring land use and land cover effects on water quality in cheung ek lake using ASTER images. American Journal of Environmental Sciences, 11(1), 1-12. doi:10.3844/ajessp.2015.1.12

Kalnay, E., \& Cai, M. (2003). Impact of urbanization and land-use change on climate. Nature, 423(6939), 528-531. doi:10.1038/nature01675

Matlhodi, B., Kenabatho, P. K., Parida, B. P., \& Maphanyane, J. G. (2019). Evaluating land use and land cover change in the gaborone dam catchment, botswana, from 1984-2015 using GIS and remote sensing. Sustainability (Switzerland), 11(19) doi:10.3390/su11195174

Uddin, M. M. M. (2015). Causal relationship between agriculture, industry and services sector for GDP growth in Bangladesh: An econometric investigation. Journal of Poverty, Investment and Development, 8.

Mondal, I., Srivastava, V. K., Roy, P. S., \& Talukdar, G. (2014). Using logit model to identify the drivers of landuse landcover change in the lower gangetic basin, india. Paper presented at the International Archives of the Photogrammetry, Remote Sensing and Spatial Information Sciences - ISPRS Archives, , XL-8(1) 853-859. doi:10.5194/isprsarchivesXL-8-853-2014

Navale, V. B., \& Mhaske, S. Y. (2019). Land use/land cover changes in sangamner city by using remote sensing and GIS. International Journal of Recent Technology and Engineering, 8(2), 4614-4621. doi:10.35940/ijrte.B3386.078219

Nicolson, L.D. (1987). The Geening of the cities; Routledge and Kegan Paul, London

Nong, D., Fox, J., Miura, T., \& Saksena, S. (2015). Built-up Area Change Analysis in Hanoi Using Support Vector Machine Classification of Landsat Multi-Temporal Image Stacks and Population Data. Land, 4(4), 1213-1231. doi:10.3390/land4041213

Park, H., Fan, P., John, R., Ouyang, Z., \& Chen, J. (2019). Spatiotemporal changes of informal settlements: Ger districts in ulaanbaatar, mongolia. Landscape and Urban Planning, 191 doi:10.1016/j.landurbplan.2019.103630

Rajeshwari D. (2006). Management of the Urban Environment Using Remote Sensing and Geographic Information Systems.J. Hum. Ecol., 20(4), 269-277. Retrieved from http://www.krepublishers.com/02_journals/JHE/ 
Rasul, A., Balzter, H., Ibrahim, G., Hameed, H., Wheeler, J., Adamu, B., ... Najmaddin, P. (2018). Applying Built-Up and Bare-Soil Indices from Landsat 8 to Cities in Dry Climates. Land, 7(3), 81. doi:10.3390/land7030081

Risma, Zubair, H., \& Paharuddin. (2019). Prediction of land use and land cover (LULC) changes using CA-Markov model in Mamuju Subdistrict. Journal of Physics: Conference Series, 1341, 082033. doi:10.1088/1742-6596/1341/8/082033

Schilling, K. E., Jha, M. K., Zhang, Y.-K., Gassman, P. W., \& Wolter, C. F. (2008). Impact of land use and land cover change on the water balance of a large agricultural watershed: Historical effects and future directions. Water Resources Research, 44(7). doi:10.1029/2007wr006644

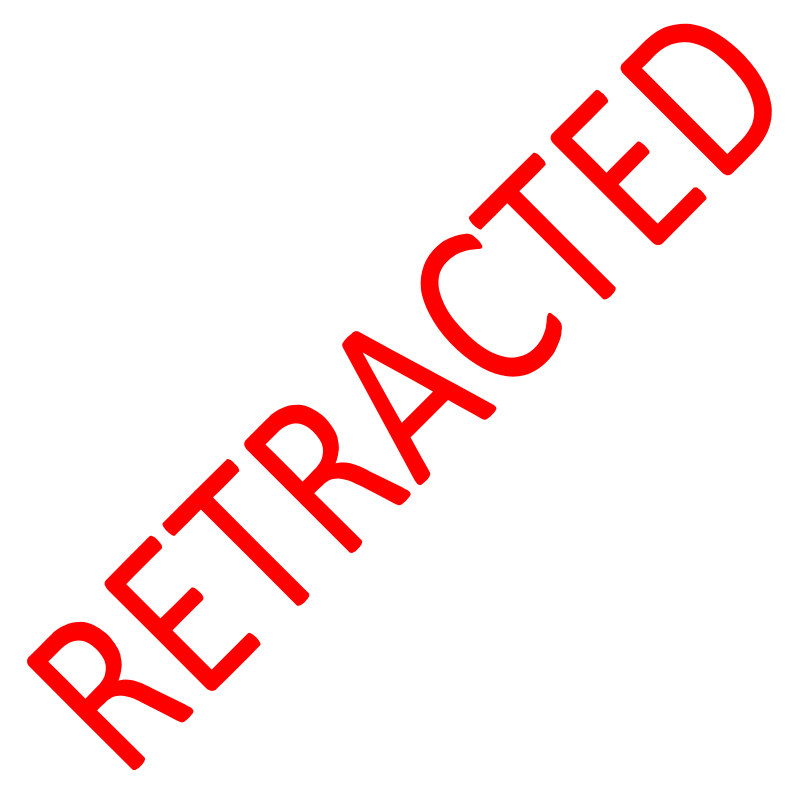

